The Classical Quarterly 70.2 806-821 (C) The Author(s), 2020. Published by Cambridge University Press on behalf of The Classical Association. This is an Open Access article, distributed under the terms of the Creative Commons Attribution-NonCommercial-NoDerivatives licence (http://creativecommons.org/licenses/by-nc-nd/4.0/), which permits non-commercial re-use, distribution, and reproduction in any medium, provided the original work is unaltered and is properly cited. The written permission of Cambridge University Press must be obtained for commercial re-use or in order to create a derivative work.

\title{
VERRIUS FLACCUS, HIS ALEXANDRIAN MODEL, OR JUST AN ANONYMOUS GRAMMARIAN? THE MOST ANCIENT DIRECT WITNESS OF A LATIN ARS GRAMMATICA*
}

When dealing with manuscripts transmitting otherwise unknown ancient texts and without a subscriptio, the work of a philologist and literary critic becomes both more difficult and more engrossing. Definitive proof is impossible; at the end there can only be a hypothesis. When dealing with a unique grammatical text, such a hypothesis becomes even more delicate because of the standardization of ancient grammar. But it can happen that, behind crystallized theoretical argumentation and apparently canonical formulas, interstices can be explored that lead to unforeseen possibilities, more exciting-and even more suitable - than those that have already emerged.

Since the publication of two papyrus fragments, both of which belong to the same original roll, the grammatical text they transmit has attracted attention because of its uniqueness, and several famous grammarians have been named as possible auctores. ${ }^{1}$ This

* The research leading to these results has received funding from the European Research Council (ERC) under the European Union's Horizon 2020 research and innovation program (Grant agreement no. 636983), ERC-PLATINUM project, University of Naples 'Federico II', which I lead as Principal Investigator. My warmest thanks to Adam Gitner (TLL, Munich) for having critically read these pages, to Costas Panayotakis for the pleasant and useful conversations and support, and to the two anonymous referees, who suggested many improvements. I am also very grateful to M.D. Reeve for having discussed with me the possibility to refer to papyrus fragments in the same way as to manuscripts.

${ }^{1}$ London, British Library Pap. 2723 + Cairo, Egyptian Museum inv. 4649 (verso) (= P.Lond. Lit. II $184+$ P.Mich. VII 429) - second-third cent. A.D.; CLA II 212+ XI 212; ChLA III 218; CPL 56+ 57; $\mathrm{MP}^{3}$ 2996; LDAB 5065; see also J.E. Dunlap, 'PMich. 429', in H.A. Sanders (ed.), Latin Papyri in the University of Michigan Collection (Ann Arbor, 1947), 2-9; A. Wouters, The Grammatical Papyri from Graeco-Roman Egypt. Contributions to the Study of the 'Ars grammatica' in Antiquity (Brussels, 1979), 93-108; J. Zetzel, Critics, Compilers, and Commentators. An Introduction to Roman Philology, 200 B.C.E. - 800 C.E. (Oxford, 2018), 330. A new, richly annotated edition of this fragmentary roll is found in M.C. Scappaticcio, Artes grammaticae in frammenti. I testi grammaticali latini e bilingui greco-latini su papiro. Edizione commentata (Berlin and Boston, 2015), 93-143, which provides a critical edition, a line-by-line commentary and further bibliographical references. The grammatical treatise is written on the back of a document, and its script is perpendicular to the script of the recto (P.Lond. inv. 2723r+P.Mich. VII 447). Although certainly belonging to the same roll, the two fragments are not adjacent. The fragments measure $7.5 \times 18.2 \mathrm{~cm}$ and $9.5 \times 21$ $\mathrm{cm}$ respectively. The grammatical side was made up of columns of $7.5 \mathrm{~cm}$, separated by an intercolumnium of $3.5 \mathrm{~cm}$ and containing at least [23] lines each; the surviving upper and lower margins measured $7.2 \mathrm{~cm}$ each, and the roll was at least [28.5] $\mathrm{cm}$ high. The script is in rustic capitals. Interpuncts are used to isolate grammatical elements and concepts, sometimes together with a raised horizontal line and/or a blank space. Further details are found in S. Ammirati, Sul libro latino antico. Ricerche bibliologiche e paleografiche (Pisa and Rome, 2015), 39. The fragment at the British Library comes from the antiquities market (bought in 1925), but, since the Michigan fragment surely comes from the University of Michigan excavations in Karanis between 1925 and 1926, there are no doubts 
meagre roll from Karanis (Kôm Aushîm, in the Fayoum) is the most ancient direct witness to a grammatical treatise, which is otherwise unknown through manuscript transmission. ${ }^{2}$ It may even be the most ancient Ars surviving through direct transmission. ${ }^{3}$

It has been previously suggested that the author could be Remmius Palaemon. The present contribution emphasizes the links of the treatise with the renowned Augustan Verrius Flaccus or with the Alexandrian model lying behind his work. Whether it is an Ars grammatica or a treatise De orthographia, the name of Varro has been reasonably excluded, ${ }^{4}$ and the evident characteristics of a grammatical treatise make the hypothesis of Pliny the Elder's authorship implausible, because his Dubius sermo is a treatise De Latinitate. Nevertheless, the text of the Karanis fragmentary roll certainly makes an undeniable contribution to the knowledge we have of fragmentary grammars and grammarians. ${ }^{5}$

\section{PARS PRIMA - AN ALEXANDRIAN-ORIENTED ARS}

The first fragment (the London fragment) contains definitions of dictio and oratio, followed by a list of the eight parts of speech, each of which must have been analysed, although only the lines concerning the noun survive. ${ }^{6}$ The second fragment (the Cairo fragment), which preserves a later portion of the treatise, discusses, first, syllable

about the roll's provenience. A third, scanty fragment has been recently identified. It will be published for the first time in the new comprehensive edition of this Ars in the Corpus of Latin Texts on Papyrus $(C L T P)$.

${ }^{2}$ P. Cherubini and A. Pratesi, Paleografia latina: tavole (Vatican City, 2004), 10, 57-8 (pl. 7) note that another fragment was supposed to join the same roll of our grammar, namely the unpublished fragment of Vienna, Österreichische Nationalbibliothek Papyrussamlung L 16. I exclude the possibility that it belongs to the same roll of our fragments. In any case, the presence of an $m$ between two medial points and with an upper horizontal stroke deserves to be emphasized, since the same way of isolating the grammatical patterns is found in our fragmentary roll and is otherwise unattested; in Cherubini and Pratesi (this note), 10 it is wrongly interpreted as $m$ (ille). Does another grammatical Latin text survive in the Viennese aforementioned fragment?

${ }^{3}$ It must be emphasized that the time of composition of the text and the time of its copying as a manuscript do not necessarily coincide.

${ }^{4}$ On the hypothetical authorship of the text, see below. Here it will be enough to emphasize that exploring the system of the parts of speech (on which, see below) is illustrative: S. Matthaios, 'Neue Perspektiven für die Historiographie der antiken Grammatik: Das Wortartensystem der Alexandriner', in P. Swiggers and A. Wouters (edd.), Grammatical Theory and Philosophy of Language in Antiquity (Leuven and Paris, 2002), 161-220, at 211-12 has convincingly explained that the approach found in the grammar from Karanis is aligned with an 'Alexandrinische Vorbilder' with influence from the Stoic tradition, while a pure Stoic tradition was followed by Varro in his De lingua Latina, determining a clear opposition between Varro and the 'römische artes'.

5 See the panorama in A. Garcea, 'Grammatici disiecti: continuità e discontinuità del pensiero linguistico antico nella nuova edizione in corso dei frammenti grammaticali latini', Latina Didaxis 31 (2016), 9-27, with further bibliography.

${ }^{6}$ London, British Library Pap. 2723 col. I: $\left.\right|^{1}[\ldots$. h]oc qu[ . ]o[ . ] . [- - - ] [ . . ]illud quod nihil[$--] \mid[+.$.$] ayt declinatione [- - - ] [ . ] . to ergo ita definit [- - - ] \left.\right|^{5}[$ vel] ut diceretur dictio: $\mid[\ldots]$ vox figuram habens | [sign]ificantiu[m] vocum. | [Na]m eiusmodi vox potest $\mid$ [di]ci, intellegi non po- $\mid{ }^{10}$ [-test]; itaque ea dictio quae | [ha]bet significationem | [in]tellectumque oratio. | [ . . a] utem oratio quasi o-|[-ris] ratio, cuius partes $\left.\right|^{15}$ [qu]idam grammatici $\mid[u]$ sque multiplicaverunt $\mid$ [] ut turba praeceptorum; col. II: $\left.\right|^{1}[$. . . ] nom[en, pronomen,] $\mid$ [ve]rbum, [p]a[rticipium,] $\mid$ [ad] verbium, con[iunc-]|-tio, praepositio, [inter-]| ${ }^{5}$-iectio. Nomen e[st vel-]|-ut notamen quo u[nam-]|-quamque rem [vo]cab[ulo] | notantes [c]ognos[cimus]; | est enim v[e]lut not[a quae-] $\left.\right|^{10}$-dam rei. Nam [.] um . [ ]|-libet, etiam si prae[sen-]|-tem non in[ve]neris[vo-]|-cabuli huius mater[iam], | tamen a voce hac n[omi-] $\left.\right|^{15}$-nis nota protinus[ spe-]|-cies rei inhaeret[ ani-]|-mo. Huius autem fin[. The text of the fragment is given according to the edition in Scappaticcio (n. 1), 115-16, but in a different layout. 
formations of double consonants and semivowels/semiconsonants, then the equivalence of the diphthongs $a e$ and $a i$, and finally the possibility that the latter diphthong contains two different syllables as a result of metaplasm. ${ }^{7}$

Until recently a different explanation of the contents of the Cairo fragment has conditioned a series of hypotheses concerning both its structure and its authorship or, at least, its typology. It was said to concern the formation of diphthongs. Since orthography precedes the parts of speech in surviving Artes grammaticae, it was assumed that it preceded the London fragment. In fact, when James E. Dunlap published the editio princeps of the Michigan fragment, he expressed no doubt that the discussion was focussed on diphthongs. This explanation was based on an emendation of the very first isolated grammatical element, the letter $x$ (line 2) into an $u$, in order to reconstruct an argument about the combination of $u$ and $i$, yielding $u i$, as well as $u$ and $a$ to form $u a$. This treatment of $u i$ and $u a$ as diphthongs is not otherwise attested in known grammatical treatises and would have a possible parallel only in a statement of Charisius and Dositheus that $u a$ was regarded as a diphthong in earlier times. ${ }^{8}$

But such a reconstruction immediately encounters an obstacle: namely it ignores the documentary text on the recto of the papyrus roll, which requires that the grammatical contents of the London fragment came before the contents of the Michigan fragment. ${ }^{9}$ As a result, the Michigan fragment must be interpreted differently, and some false corrections of the transmitted text can be avoided. ${ }^{10}$ The topic of syllable formation seems to be at issue, beginning with the difficult status of double consonants - that is, $x$ at line 2-and semivowels/semiconsonants-that is, $u$ at lines 3-6. Next comes the equivalence of the diphthongs ae and $a i$, exemplified by a Virgilian hexameter (Aen. 9.26), which is said to contain two syllables instead of one as a consequence of metaplasmus (line 16). This kind of argumentation is not unique, as it is paralleled either in Artes grammaticae, specifically in their chapters De vitiis et virtutibus orationis, or in treatises De orthographia.

${ }^{7}$ Cairo, Egyptian Museum inv. 4649 (verso): [vo-] $\left.\right|^{1}$-cali, ut puta si prae[ponas] $\mid x$ litterae i faciat [xi, tam] | mehercule quam $v$ [ et a faci-]|-at va. Simili rati[o]n[e si] $\left.\right|^{5}$ iunx[e]ris vocali a et [u faci-]|-at au item a et e fac[iat ae.] | Nam non debere hanc [syl-]|-labam a et e scribi man[i-]|-festum est $m[u] l t i s$ ex rebu[s, pri-]| ${ }^{10}$-mum m[a]x[i]m[u]mque quod G[rae-]|-ci, a q[u]i[b]u[s] nos usum li[tte-]|-rarum accepimus, per a[ et i] | scribunt hanc sy[l]lab[am;] | deinde poetae ma[ ] $\left.\right|^{15}$ hoc efficiunt a e[t $i, u t] \mid$ cum [met] aplasm[o diduca-]|-tur ha[e]c sy[llaba una] | in dua[s, i]ta [ut Vergilius pro] | 'dives [pict]ae' a [i]t '[dives pic-] $\left.\right|^{20}[$-tai] v[est]is et au[ri'] $\mid[\ldots \ldots$. . $]$ oc no[n $\mid[\ldots \ldots . .]$. nisi $h[\mid]$. . [. The text of the fragment is given according to the edition in Scappaticcio (n. 1), 117, although in a different layout.

${ }^{8}$ Charisius, Gramm. 1.4 = 8.19-20 K. Barwick, Flavii Sosipatri Charisii Artis grammaticae libri V (Leipzig, 1964 ${ }^{2}$ ): syllabae natura longae, cum singulae vocales litterae producantur, ut a aut e, aut cum duae, ut ua; Dositheus, Gramm. 11=24.11-12 G. Bonnet, Dosithée. Grammaire latine (Paris, 2005): natura longae fiunt, cum singulae vocales litterae producuntur, ut a et e, aut cum duae, ut ua. See J.E. Dunlap, 'Fragments of a Latin grammar from Egypt', AJPh 61 (1940), 330-44, at 331-3; id. (n. 1), 4.

${ }^{9}$ The London fragment surely comes before the Cairo fragment, and such a sequence is easily explained by looking at the documentary recto. An in-depth analysis is found in Scappaticcio (n. 1), 98-101, where the previous reconstructions are considered. It follows that the relationship between the two fragments has significance for the relationship between the grammatical sections they transmit.

${ }^{10}$ Although not impossible, it seems not to be a plausible correction of the $x$ at line 2, especially because it represents one of the grammatical elements that are clearly isolated by the scribe. In fact, the letter is marked by a horizontal line above it and by a dot in the medial position at either side. The same signs - that is, a horizontal line and two medial dots - are employed to isolate letters or couples of letters which are discussed in the grammatical argumentation, and such a distinctive graphic system is evidently a peculiarity of this grammar. Words discussed (and even exempla) are emphasized only through the employment of the horizontal line above. 


\section{Parts of speech}

In our papyrus grammar, the definition of oratio stands as the starting point for the sections on the parts of speech, 'the core of ancient grammatical science'. ${ }^{11}$ These are polemically introduced by a reference to the multiplicatio of their number by certain grammarians. ${ }^{12}$ The references to quidam grammatici and to turba praeceptorum (variously interpreted) identify respectively the theoretical and the practical aspects of grammatical reflection, perhaps drawing attention to a deviation from the grammatical canon because of the effects that praxis could have on the canon itself. ${ }^{13}$ Whether or not these references to grammatici and to praeceptores provide identifying details about the auctor, the only certainty is its undoubtedly polemical tone.

The eight parts of speech are given as follows: nomen, praenomen, verbum, participium, adverbium, coniunctio, praepositio, interiectio. ${ }^{14}$ With the exception of the omitted öp $\theta \rho o v$ and the placement of pronomen and interiectio in the second and eighth places, this sequence follows the canonical order, which had its roots in Stoic linguistic thought. They placed the indeclinable parts of speech after the declinable ones, as reflected in the Alexandrian grammatical treatise attributed to Dionysius Thrax. ${ }^{15}$ The identical list is also found in the late antique grammars of Diomedes - who nevertheless adds a ninth part, appellatio, introduced by Terentius Scaurus ${ }^{16}$ - and of Maximus Victorinus. ${ }^{17}$ In Charisius' grammar, the number of eight parts of speech is preserved, although the adverb precedes the participle, ${ }^{18}$ while in Dositheus' grammar the preposition precedes the conjunction, ${ }^{19}$ and further differences are found in the Instituta artium. ${ }^{20}$

${ }^{11}$ P. Swiggers and A. Wouters, 'Condensed grammatical knowledge in antiquity: doxographical accounts of the parts-of-speech system', in M. Horster and C. Reitz (edd.), Condensing Texts Condensed Texts (Stuttgart, 2010), 135-63, at 135; this contribution is a point of reference and offers further bibliography on the theme.

12 London, British Library Pap. 2723 col. I line 15.

13 See Scappaticcio (n. 1), 123-5 for further details and bibliography.

14 London, British Library Pap. 2723 col. II lines 1-5; see the analytic commentary in Scappaticcio (n. 1), 125-8 (with further bibliographical references).

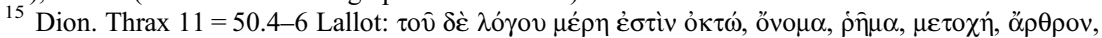

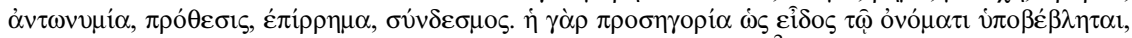
on which see J. Lallot, La grammaire de Denys le Thrace (Paris, 1998²), 122-5. The implicit reference to the opposition between vox articulata and vox inarticulata in our papyrus grammar goes back to Stoic theories, contrary to Varro; see P. Swiggers, 'A note on the grammatical papyrus P. Lit. Lond. 184', Aegyptus 64 (1984), 31-4 and M.C. Scappaticcio, 'Significans vox: (Anon. gramm. P.Lond. Lit. II 184 lines 6-7)' (forthcoming).

${ }^{16}$ GL 1.300.26-301.2 Keil: partes orationis sunt octo, nomen pronomen verbum participium adverbium coniunctio praepositio interiectio; Scauro videtur et appellatio. Ex his primae quattuor declinabiles sunt, sequentes indeclinabiles. Latini articulum, Graeci interiectionem non adnumerant.

${ }^{17}$ GL 6.197.23-205.4 Keil.

18 Charisius, Gramm. 1.5 = 193.7-8 Barwick: orationis partes sunt octo, nomen pronomen verbum adverbium participium coniunctio praepositio interiectio. See the different order in the Ars Bobiensis (M. De Nonno, La grammatica dell'Anonymus Bobiensis (GL I 533-565 Keil), con un'appendice carisiana [Rome, 1982], 4-6): orationis partes sunt octo: nomen pronomen verbum adverbium participium praepositio coniuntio interiectio; quibusdam videtur et appellatio.

19 Dositheus, Gramm. 14=29.4-6 Bonnet: orationis partes sunt octo, nomen pronomen verbum participium adverbium praepositio coniunctio interiectio; quibusdam videtur et appellatio. It has already been observed that the debate was focussed on the way in which the parts were coupled, that is, participium and adverbium, on one side, and praepositio and coniunctio, on the other; see L. Holtz, Donat et la tradition de l'enseignement grammatical (Paris, 1981), 67-9 and Bonnet (n. 8), 121-2.

${ }^{20}$ GL 4.51.18-19 Keil: partes orationis sunt octo, nomen pronomen participium adverbium coniunctio praepositio interiectio verbum. 
I.1. NOMEN $\sim$ The occurrence of nomen provides an important clue to the grammatical context. In the first book of his Ars grammatica, Charisius reports Julius Romanus' argument on the basis of analogy. ${ }^{21}$ The exemplum of Turbo Turbonis and turbo turbinis demonstrates a difference between Pliny's and Caesar's theories of analogy. ${ }^{22}$ In particular, Pliny-contrary to Caesar-infers from this difference in inflection that the category of vocabulum ( $\pi \rho \circ \sigma \eta \gamma o \rho i \alpha$, 'common noun') must be distinguished from the nomen (ővo $\alpha$, 'proper noun'). Consequently, the number of parts of speech for him could have been higher than the eight which came directly from the Greek grammatical tradition. ${ }^{23}$ Such a distinction between vocabulum and nomen, which seems to have been accepted by Pliny the Elder in his Dubius sermo-according to Julius Romanus and then Charisius-does not belong to the grammatical doctrine of our grammar. In the London fragment, vocabulum occurs more than once in order to clarify the concept of nomen and is included in its definition. ${ }^{24}$ Vocabulum is already part of the word-class of nomen in the Alexandrian doctrine. ${ }^{25}$

Comparison with the parts of speech in the Institutio oratoria could provide a further explanation. According to Quintilian, some veteres such as Aristotle and Theodectes simply used to list verba, nomina and convictiones (or coniunctiones); later the number of parts of speech was increased by some philosophers, especially the Stoics, eventually growing to eight and then nine. ${ }^{26}$ Although the distinction between nomen and vocabulum made the number of the parts of speech reach nine, at the same time eight was still supported by some grammarians, including Aristarchus and Remmius Palaemon. The reference to Aristarchus goes back to the Greek grammatical theories of the Alexandrian Age, while the reference to Palaemon alludes to a grammarian a few years older than Quintilian. This chronological gap can now be filled through Dionysius Thrax, on the Greek side, and Caesar and his De analogia and the Rhetorica ad Herennium, ${ }^{27}$ on the Latin side. Perhaps the name of Verrius Flaccus can be added.

Like Caesar, Verrius made analogical principles shape his grammatical argumentation. This is apparent from some fragments of his work, in particular his theory of morphology. ${ }^{28}$ Ratio - in other words analogy-is counted among the three exegetical

${ }^{21}$ See the beginnings of Charisius, Gramm. 1.17=149.21 Barwick: de analogia, ut ait Romanus.

22 Charisius, Gramm. 1.17=183.19-24 Barwick: Turbo Turbonis, si proprium sit hominis nomen; turbinis, si procellam voluerimus exprimere, aut in eo, inquit Plinius, qui est in lusu puerorum. Sed Caesar de analogia II turbonem, non turbinem etiam in tempestate dici debere ait, ut Cato Catonis, non ut homo hominis. These lines are given both in the edition of Pliny's Dubius sermo (A. Della Casa, Il Dubius sermo di Plinio [Genoa, 1969], 143 no. 71) and in the edition of Caesar's De Analogia (A. Garcea, Caesar's De Analogia [Oxford, 2012], 215 no. 21). See the comment on these lines in Garcea (this note), 215-17. A rich analysis on this passage is offered by G. Calboli, 'Grammatica e stilistica latina tra Varrone e Quintiliano', Latina Didaxis 28 (2013), 31-54, at 42-4.

${ }^{23}$ As for the possibility that the Greek grammatical tradition going back to Aristarchus was absorbed by Caesar via Varro, see Garcea (n. 22), 39. Such an argument rebuts the remote possibility-discussed by G. Pennisi, 'Ad grammaticos', Helikon 1 (1961), 496-511 — that the Karanis grammar can be identified with Pliny's Dubius sermo.

${ }^{24}$ London, British Library Pap. 2723 col. II lines 7 and 12-13.

25 See R. Gutiérrez González, 'Stoics on tropes and figures', Journal of Latin Linguistics 15 (2016), 279-311, at 293, with relevant passages and bibliography.

${ }^{26}$ Quint. Inst. 1.4.17-21; on which, see recently W. Ax, Quintilians Grammatik (Inst. orat. 1, 4-8). Text, Übersetzung und Kommentar (Berlin and Boston, 2011), 120-34 and Gutiérrez González (n. 25), 293.

27 See Calboli (n. 22).

${ }^{28}$ I. Funaioli, Grammaticae Romanae Fragmenta I (Leipzig, 1907), fr. 15 Verrius (from 
'instruments' Verrius Flaccus was accustomed to use, together with exempla and auctoritas, and he himself offered a demonstration of their employment in his correspondence, according to the commentator Servius on Aen. 8.423. ${ }^{29}$ Ratio is a key word (and thus a key concept) in some passages from Velius Longus' treatise on orthography that have been connected to Verrius Flaccus. ${ }^{30}$

I.2. INTERIECTIO $\sim$ The presence of interiectio among the parts of speech led the first editor of the London fragment, Herbert J.M. Milne, to hypothesize that the grammar was linked to Remmius Palaemon, the Latin grammarian who introduced interjection among the parts of speech, according to his contemporary Quintilian. ${ }^{31}$ It was 1927, and Milne

Charisius): clunes - Verrius Flaccus masculino genere dici probat, quoniam nis syllaba terminata anima carentia nominativo singulari masculina sunt, ut panis cinis crinis et similia; 17 (from Charisius): hic [sc. nomen excidit] masculine dicendus est, ut Verrius ait quoniam neutra in $i$ et us non exeunt; 21 (from Charisius): 'diligente Verrius Flaccus' inquit Plinius; eorum nominum quae ns finiuntur casu nominativo ablativus in e derigendus est; 22 (from Charisius): ns litteris terminata uno modo ex se faciunt adverbia ter terminata, ut decens decenter. Non nulli etiam ex participiis putaverunt talia figurari, ut Verrius Flaccus, qui ab eo quod est audens audenter; 25 (from Charisius): gibber, ut Verrius ait, ipsum vitium dicitur, ut tuber, gibberosus habeas gibberem, ut tuberosus. All these fragments are incertae sedis, and cannot be ascribed with certainty to a specific work of Verrius. On Verrius and analogy, see R.A. Kaster, C. Suetonius Tranquillus. De Grammaticis et Rhetoribus (Oxford, 1995), 192: 'V.'s morphological views reveal a clear (though not exclusive) reliance on the principles of analogy.'

29 Serv. Verg. Aen. 8.423: antea 'hoc' adverbium loci fuit, quod nunc abolevit: nam crebro in antiquis lectionibus invenitur, sicut in epistulis probat Verrius Flaccus exemplis auctoritate ratione, dicens in adverbiis pro ' $u$ ' 'o' plerumque maiores ponere consuetos. This is the only explicit quotation of Verrius Flaccus in the commentary of Servius, and it is impossible to know whether Servius was directly consulting the work of Verrius Flaccus or another work possibly mentioning him. But this passage from Servius' commentary is relevant for several reasons, and not simply because it mentions some of Verrius' otherwise unknown epistles; on the grammatical correspondence of Verrius Flaccus, see A. Garcea, 'Un genre mineur: la lettre grammaticale', in M. Baratin, C. Lévy, R. Utard and A. Videau (edd.), Stylus: la parole dans ses formes. Mélanges en l'honneur du professeur Jacqueline Dangel (Paris, 2010), 163-76. On the presence of the work of Festus in the late antique commentators of Virgil, see D. Vallat, 'Une présence silencieuse: Festus et les commentaires virgiliens', Eruditio Antiqua 6 (2014), 131-51.

${ }^{30} \mathrm{See}$, for instance, Vel. Orth. $5.3=31.8-11$ M. Di Napoli, Velii Longi De orthographia (Hildesheim, 2011): quaeritur item 'Iulii' et 'Claudii' et 'Cornelii' utrum per unum 'i' productum an per duo debea $n \backslash t$ scribi. Et ratio exigit ut huius 'Iulii' per duo 'i' scribamus, tam hercule[m] quam huius 'pallii' et huius 'graphii', on which see the commentary of Di Napoli (this note), 118-19 and further notes in P. De Paolis, 'Recta scriptura e recte scribendi scientia: l'ortografia latina in epoca imperiale fra prassi e insegnamento', in F. Biddau (ed.), Die geheimen Mächte hinter der Rechtschreibung. Erfahrungen im Vergleich / L'ortografia e $i$ suoi poteri forti. Esperienze a confronto (Frankfurt am Main, 2013), 35-53, at 47-9.

${ }^{31}$ H.J.M. Milne, Catalogue of the Literary Papyri in the British Museum (London, 1927), 153-4: 'the mention of the interjection among the parts of speech perhaps points to the authorship of Q. Remmius Palaemon, the introducer of this classification according to Quintilian his contemporary (Inst. Or. I. 4. 20).' See Quint. Inst. 1.4.19-20 (the full context is given below); on these lines, see Ax (n. 26), 128-9 (with a specific reference at 131 to the grammar on the papyrus under discussion) and Calboli (n. 22), 39, where further bibliography can be found. Matthaios (n. 4), 211 is also a reference point which deserves to be mentioned, although the sequence established between Remmius Palaemon and the grammar from Karanis at 212 (schema VI) is debatable. It is worth noting that Schol. Iuv. 6.452 claims that Remmius Palaemon was Quintilian's teacher; there are no other texts confirming such a possibility; on Remmius Palaemon, see recently M. Pozdnev, 'De Remmii Palaemonis indole vitiisque', Philologia classica 11 (2016), 253-7 and Zetzel (n. 1), 70-1, 74-7, 163-4, 305-6 (with further bibliographical references). It must be emphasized that Milne did not systematically discuss the matter of the authorship of the grammar, but simply formulated the hypothesis of Remmius Palaemon in his brief edition of the London fragment. 
did not know the Michigan fragment, which was first published more than ten years later.

What Milne shyly introduced as a hypothesis was attractive enough to persuade Jean Collart. In 1938, he published an article in the Revue de Philologie, which offered further arguments in favour of Remmius Palaemon; in particular, a) similarities in the discussion of the numbers of the parts of speech; b) the proverbial arrogance of Remmius Palaemon in relation to the scornful reference to a turba praeceptorum; ${ }^{32} \mathrm{c}$ ) the palaeographical dating of the papyrus, which excludes Late Antiquity and points to the very narrow field of grammarians active in the first century. ${ }^{33}$

When the Michigan fragment was published and joined to the London fragment, the new edition by James Dunlap took a more cautious approach to authorship. ${ }^{34}$ Even Pliny the Elder has been considered, in 1961 by Giuseppe Pennisi, who tried to argue that the label of 'grammar' could not fit the text of our fragmentary roll, which he attributed to Pliny's Dubius sermo. ${ }^{35}$

The presence of interiectio among the parts of speech in the London fragment has been read as a terminus post quem, since Remmius Palaemon is said to have introduced such a category into Roman grammatical theory. ${ }^{36}$ This hypothesis is based on the sixteenth chapter of the second book of the Ars grammatica of Charisius, de interiectione, which starts with the explanation of what an interjection is and the different definitions by Cominianus, Remmius Palaemon and Julius Romanus—not following chronological order. ${ }^{37}$ But were Remmius Palaemon, Julius Romanus and Cominianus the only sources for Charisius' claim, especially considering that in the same chapter Varro is mentioned as well? And was Charisius consulting only the grammars of Remmius Palaemon, Julius Romanus and Cominianus, or was he citing the most ancient theories second-hand from more recent artes (or even excerpta)? And what prevents one from thinking that Palaemon was taking his arguments about interjection from a previous source? After all, the reason why Quintilian mentions Palaemon seems to involve only sharing the number of eight parts of speech and representing the Latin counterpart to Aristarchus.

But the supposed gap between Aristarchus and Remmius Palaemon needs to be reconsidered, since Dionysius Thrax incorporated the grammatical theories of Aristarchus, and Verrius Flaccus is known to have later absorbed the principles of grammatical theory from Dionysius Thrax, from the Rhetorica ad Herennium, from Varro and from Caesar's De analogia. ${ }^{38}$

32 London, British Library Pap. 2723 col. I line 17.

33 J. Collart, 'Palémon et l'Ars grammatica', RPh 12 (1938), 228-38, on which see Dunlap (n. 8), 335-6.

34 See Dunlap (n. 8), 336-7.

35 See Pennisi (n. 23), whose arguments have produced several doubts; a detailed discussion is found in Wouters (n. 1), 104-6 and in Scappaticcio (n. 1), 104-6, where updated bibliographical references are found and another argument against the authorship of Pliny the Elder is introduced.

${ }^{36}$ See Collart (n. 33), 231; Wouters (n. 1), 106. On the interjection and the Roman grammarians, see the general contribution of M. Pugliarello, 'Interiectio: espressività e norma nella teoria grammaticale latina', BStudLat 26 (1996), 69-81.

${ }^{37}$ Charisius, Gramm. 2.16=311.4-312.2 Barwick. It is worth noting that in the section de inter-

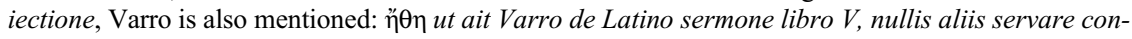
venit, inquit, quam Titinio Terentio Attae; $\pi \dot{\alpha} \theta \eta$ vero Trabea, inquit, Atilius Caecilius facile moverunt (...) praecise, inquit Varro, generat animi passionem. Quod novi generis cum non sit interiectio sed ademptio, tamen interiecti animi causa vocitamus (315.3-12).

${ }^{38}$ It is worth emphasizing that in the Roman tradition interjections are not necessarily dependent on 
I.3. ETYMOLOGICAL DEFINITIONS OF GRAMMATICAL CONCEPTS $\sim$ The treatise defines the concept oratio as quasi oris ratio-exactly as can be found later in Charisius, Diomedes and Dositheus-and nomen as velut notamen. ${ }^{39}$ A certain inclination towards etymological definitions is evident in the treatise, and it is as a feature shared with the works by Verrius Flaccus. In Verrius' works, in fact, etymology plays the decisive role of recovering the essence of words and things. ${ }^{40}$

Verrius Flaccus is the source to which some etymological arguments from Velius Longus' orthographical treatise have been ascribed. For instance, a predilection towards

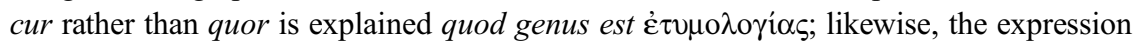
tam hercule quam recalls the tam mehercule quam in our grammar. ${ }^{41}$ Was Verrius' orthographical treatise also based on the etymological criterion for definitions, among other considerations? What is found in Velius Longus and what survives in scanty fragments transmitted indirectly would suggest a positive answer to this question. ${ }^{42}$

\section{Elements of speech}

Verrius Flaccus' grammatical theories also lie behind striking similarities that the grammar from Karanis shares with the orthographical treatises of Velius Longus and Terentius Scaurus. Verrius Flaccus was one of the most authoritative grammarians of the Augustan Age. A statue of him was erected in the town of Praeneste, possibly his hometown, and Verrius became famous enough to be invited by Augustus to teach his grandchildren. ${ }^{43}$ Among his extremely varied works, the lost De orthographia

the Palaemonian theorization; see recently Groupe Ars Grammatica (edd.), Priscien. Grammaire Livres XIV-XV-XVI. Les invariables (Paris, 2013), 36-7, 215-19.

39 London, British Library Pap. 2723 col. I lines 13-14; as for the parallelisms with the abovementioned late antique grammarians, see Scappaticcio (n. 1), 120-1, 122-3. Col. II lines 5-8: nomen velut notamen quo unamquamque rem, vocabulo notantes, cognoscimus, on which see Scappaticcio (n. 1), 129-30. In Festus' De significatu verborum an etymological definition of nomen is also given; see Fest. 179.13: nomen dictum quasi novimen, quod notitiam facit, on which see A. Luhtala, 'Latin Schulgrammatik and the emergence of grammatical commentaries', in M. Horster and C. Reitz (edd.), Condensing Texts - Condensed Texts (Stuttgart, 2010), 209-43, at 232 , where it is stated that an etymological approach to the parts of speech 'can be criticized for failing to display a clear awareness of metalanguage'.

${ }^{40}$ On this specific aspect, see M.K. Lhommé, 'Les erreurs de Festus? Verrius Flaccus à l'œuvre', Eruditio Antiqua 6 (2014), 113-28, where etymology and aetiology are defined as 'moteurs de recherche' (at 124) in Verrius Flaccus' works and especially in his De verborum significatu.

41 Cairo, Egyptian Museum inv. 4649 (verso) lines 2-3, on which see below.

42 A few fragments are attributed by Funaioli to Verrius' De orthographia; see frr. 5-13 ('ad libros De orthographia certa fere ratione pertinent', Funaioli [n. 28], 515). Among these fragments some evidently reveal a certain taste towards etymological definitions, such as fr. 8 (manibias per duo $i$ dicendum, quia sunt a manibus, ut putat Verrius-from Charisius); 9 (nomenclator sine u dicitur, ut Verrius ait, velut nominis calator-from Charisius). For a historical contextualization of this topic, see A. Luhtala, 'On definitions in ancient grammar', in P. Swiggers and A. Wouters (edd.), Grammatical Theory and Philosophy of Language in Antiquity (Leuven, Paris and Sterling, 2002), 257-85.

43 On Verrius Flaccus, see Suet. Gram. et rhet. 17, on which Kaster (n. 28), 190-6. On Verrius' De significatu verborum, see recently E.A. Grandazzi, 'Les mots et les choses: la composition du De verborum significatu de Verrius Flaccus', REL 69 (1991), 101-23; M.K. Lhommé, 'Le "De verborum significatione" de Verrius Flaccus aux "Glossaria Latina" de Lindsay: éditions de lacunes, lacunes des éditions', ŽAnt 51 (2001), 39-62; P. Pieroni, Marcus Verrius Flaccus' De Significatu Verborum in den Auszügen von Sextus Pompeius Festus und Paulus Diaconus. Einleitung und Teilkommentar (154, 19-186, 29 Lindsay) (Bern and Frankfurt am Main, 2004); M.K. Lhommé, 'Varron et Verrius au 2éme siècle après Jésus-Christ', in F. Glinister and C. Woods (edd.), Verrius, Festus and Paul: Lexicography, Scholarship, and Society (London, 2007), 32-47; ead. (n. 40); 
was the first Latin treatise of its kind, ${ }^{44}$ and necessarily became the sourcebook for all subsequent orthographers. ${ }^{45}$

Both Velius Longus and Terentius Scaurus wrote their treatises in the period of the Emperor Hadrian, and their undeniable points of contact have been explained as prototypical traits of the genre de orthographia. Common elements between Cornutus' De enuntiatione vel orthographia and the grammatical chapters of Quintilian's Institutio oratoria suggest a common source, and such a source has been identified with Verrius Flaccus, whose lost De orthographia is the only authoritative work mentioned in the surviving orthographical tradition. ${ }^{46}$

II.1. MEHERCVLE! A few observations on tam mehercule quam are instructive. Since the treatise's first publication it has been emphasized that tam mehercule quam is similar to the tam Hercule quam frequently attested in the Artes grammaticae and especially to one striking example in the orthographical treatise by Velius Longus. ${ }^{47}$ Perhaps this is not by chance.

The occurrences of tam Hercule quam in Velius Longus are in passages where Verrius Flaccus might be inferred as a source. In fact, tam Hercule quam is found while discussing the genitive form $i$ instead of $i i$ and just a few lines before the argumentation on the equivalence of $a e$ and $a i$, where Aen. 9.26 is cited as an illustration (exactly as in our anonymous fragmentary grammar). ${ }^{48}$ Both this passage and a later passage on the correct orthography of $\mathrm{cur}^{49}$-where tam Hercule quam occurs as

A. Aragosti, 'Hermeneumata Festina', SCO 61 (2015), 241-312; Zetzel (n. 1), 96-8 and 231 (with further bibliography). On the originality of Festus' work, see C. Codoñer, 'El "de significatu verborum" de Festo: ¿un compendio?', in L. Cristante and L. Veronesi (edd.), Forme di accesso al sapere in età tardoantica e altomedievale 6. Raccolta delle relazioni discusse nell incontro internazionale di Trieste, Biblioteca statale, 24-25 settembre 2015 (Trieste, 2016), 1-38.

${ }^{44}$ Suet. Gram. et rhet. 19: Scribonius Aphrodisius, Orbili servus atque discipulus, mox a Scribonia Libonis filia, quae prior Augusti uxor fuerat, redemptus et manumissus docuit quo Verrius tempore. Cuius etiam libris de orthographia rescripsit, non sine insectatione studiorum morumque eius, on which see Kaster (n. 28), 204-5 and, more recently, Zetzel (n. 1), 61-3.

${ }^{45}$ See F. Desbordes and A. Garcea, s.v. 'Verrius Flaccus, Marcus', in H. Stammerjohann (ed.), Lexicon grammaticorum. A Bio-Bibliographical Companion to the History of Linguistics (Tübingen, 2009), 1569-70, at 1569. On the orthographical treatise by Verrius, L. Mackensen, De Verrii Flacci libris orthographicis (Leipzig, 1896) stands as a point of reference.

46 This hypothesis was formulated by Mackensen (n. 45) and-although disputed by E. Neitzke, De Velio Longo grammatico (Göttingen, 1927), 55-has recently been strengthened by Di Napoli (n. 30), xlvi-liii, who says that Verrius Flaccus is the main source for the orthographic treatise by Velius Longus. Verrius was also one of the main sources of Terentius Scaurus, who seems to have used Verrius' orthographical treatise directly; see F. Biddau, Q. Terentii Scauri De orthographia (Hildesheim, 2008), xlv-li. According to Biddau (this note), xlv-xlvi, it is impossible to know whether Terentius Scaurus and Velius Longus were consulting Verrius Flaccus directly or absorbing Verrius' theories through Remmius Palaemon. The hypothesis that Terentius Scaurus was even (implausibly as it seems) counted among the possible sources of the author of the grammar from Karanis was formulated by V. Law, "An unnoticed late Latin grammar: the "Ars minor" of Scaurus?', RhM 130 (1987), 67-89, at 84-7.

47 See Dunlap (n. 8), 342: 'the similarity [sc. with Velius Longus] is much too close to be entirely accidental, but its precise significance cannot be determined'; see also id. (n. 1), 5-6, on which Scappaticcio (n. 1), 134. The expression tam mehercule quam has been defined as the 'espressione più caratteristica di questa colonna' by Pennisi (n. 23), 509, who also used this formula to strengthen his argumentation for the authorship of Pliny the Elder; see also Scappaticcio (n. 1), 133-5.

${ }^{48}$ Vel. Orth. $5.3=31.8-11$ Di Napoli: quaeritur item 'Iulii' et 'Claudii' et 'Cornelii' utrum per unum ' $i$ ' productum an per duo debea<n〉t scribi. Et ratio exigit ut huius 'Iulii' per duo ' $i$ ' scribamus, tam hercule [m] quam huius 'pallii' et huius 'graphii', on which Di Napoli (n. 30), liii and 118-19.

${ }^{49}$ Vel. Orth. 8.4.3=61.11-16 Di Napoli: nos ad brevitatem festinavimus scribendi et illam 
well-have been attributed either to Verrius Flaccus as an intermediary for Varro's grammatical theories or to Verrius Flaccus himself. Verrius Flaccus is explicitly mentioned by Charisius as one of the sources for his section on the formation of adverbs from participles, where a tam Hercule quam occurs. ${ }^{50}$

II.2. SYLLABLE FORMATION, THE GRAECI AND THE VSVS LITTERARVM As in the above-mentioned passage from the orthographical treatise of Velius Longus, the anonymous writer also quotes the Virgilian hexameter Aen. 9.26 while explaining the equivalence of the diphthongs $-a e-$ and $-a i-$ in the anonymous papyrus grammar. ${ }^{51}$ The text is focussed on the combination of $a$ and $e$ and on the preference for the form $-a i-$ instead of $-a e-$ because of its proximity with the Greek $-\alpha-$. The anonymous grammarian presents this usage as a necessary and obvious statement, and clearly frames it as a matter of written form-which suggests a strong interest in orthography. The preference for $a i$ instead of $a e$ is said to be defensible from several perspectives, but the main reason is its parallelism with Greek, and, in turn, Graeci are the source from which Romans derived their usus litterarum.

It cannot be determined who these Graeci are, but what is certain is that a) they represent his theoretical point of reference, and b) their customary preference overlaps with the preference attributed to the antiqui by Velius Longus in the same explanation of ae/ai in his de orthographia. Perhaps this similarity is not by chance, and it might imply some chronological distance between the anonymous grammarian and Velius Longus. In fact, if this anonymous grammarian endorsed the Graeci, he supported the preference for $a i$ and he may have been considered an antiquus by a grammarian who lived under the Emperor Hadrian. This would imply either the dependence of Velius on our Anonymus (or on his source, or on a grammarian sharing the same credo), or a chronological relationship between them, with the Anonymus being more ancient (or archaizing?) in comparison to Velius. Nevertheless, a divergent grammatical framework could also explain the different references to the Graeci and the antiqui. However, Charisius will later connect the veteres-not the antiqui-with the

pinguitudinem limare maluimus, tam hercule quam 'cur' magis 〈scribimus quam 'quor'〉 quod genus

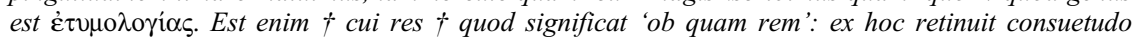
hodierna ut diceremus 'quare', † quo † una syllaba castigatum sit 'cur', quod nos contenti sumus per 'c'scribere, on whose possible source see Di Napoli (n. 30), liii. A third occurrence of the expression tam hercule quam is registered at Vel. Orth. 13.10=79.18-23 Di Napoli: 'locutionem' quoque Antonius Rufus per ' $q$ ' dicit esse scribendam, quod sit ab eo quod est 'loqui'; item 'periculum' et 'ferculum'. Quae nomina contenta esse 'c' littera existimo, tam hercule quam illo $s\rangle$ vitiose et dicere et scribere existimo, ‘qui) per 'quo' 'quotidie' dicunt, cum per 'co' 'cotidie' [cum] et dicatur melius et scribatur. Non enim est a 'quoto die' 'quotidie' dictum, sed a 'continenti die' 'cotidie' tractum, on which Di Napoli (n. 30), 154-5; this passage has been connected to the grammarian Nisus, and where the grammarian Antonius Rufus is mentioned several possible sources of Velius Longus are discussed by Di Napoli (n. 30), 148-9.

${ }^{50}$ Charisius, Gramm. $2.12=238.1-11$ Barwick: $n$ s litteris terminata uno modo ex se faciunt adver-

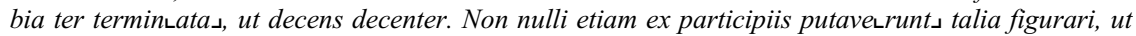

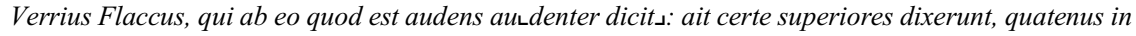

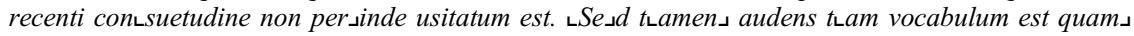
participium; | et cum ex se adverbium facit, vocabuli vicem obtinet, tam he $\llcorner$ rcule $\lrcorner$ quam cum recipit comparationem. Nam sicut comparationem non recipi $\llcorner$ unt $\lrcorner$ participia, ita ne 〈in〉 adverbia quidem transeunt. As for the link between Varro and Verrius, see Lhommé (n. 43 [2007]), where Varro is analysed as being one of the sources of Verrius.

${ }^{51}$ Cairo, Egyptian Museum inv. 4649 (verso) lines 7-20. This passage is analysed in depth by Scappaticcio (n. 1), 136-43, where additional references to ancient parallels and bibliography are found. Wouters (n. 1), 100-1 is also an essential bibliographical reference. 
Graeci. ${ }^{52}$ Whether the word Graeci of the Anonymus simply recalls a well-known Greek custom or a Greek grammatical exemplum and whether such a Greek model was perhaps Alexandrian are impossible to determine with certainty because of the scantiness of the grammar from Karanis. One possibility worth investigating may be Trypho. ${ }^{53}$

One certainty seems to be clear: one of the proposed authors of the anonymous grammar from Karanis, Remmius Palaemon, is well known for his opposition to the veteres. ${ }^{54}$ Accordingly, the anonymous treatise's emphasis on the Graeci is not easy to square with Palaemon as author.

The reference to usus litterarum is a key element shaping the nature of the discussion in the grammar from Karanis. ${ }^{55}$ In fact, talking about the 'use of letters' is a transparent attempt to address orthography. The parallelism with what can be read in the Institutio oratoria and its section on orthography is even more significant, since Quintilian's source has been reconstructed as a grammatical treatise obviously dealing with orthographical matters, possibly the grammatical treatise of Verrius Flaccus. ${ }^{56}$ Moreover, together with consuetudo, usus is a decisive parameter that analogy obeys, and its opposition to regula/ratio is the focus of arguments developed in the fully preserved works de orthographia. ${ }^{57}$

\section{Vitia et virtutes}

In the anonymous grammar from Karanis, only poets are said to have kept the disyllabic use of -ai, a metrical effect specifically called metaplasmus. This is demonstrated with a quotation of the famous dives pictai of the Aeneid. ${ }^{58}$ The same verse of Virgil is mentioned in several grammars, and in several different chapters, ${ }^{59}$ but significantly it is used frequently in orthographic arguments as evidence for the equivalence of the endings $a i$ and $a e$. This includes Velius Longus and later Marius Victorinus, in both cases

52 Charisius, Gramm. 1.5 = 14.9 Barwick: veteres secuti Graecos. On this passage and its context, see M. De Nonno, 'Vetustas e antiquitas, veteres e antiqui nei grammatici latini', in S. Rocchi and C. Mussini (edd.), Imagines Antiquitatis. Representations, Concepts, Receptions of the Past in Roman Antiquity and the Early Italian Renaissance (Berlin and Boston, 2017), 213-47, at 239-40 (with further bibliography) on the meaning of veteres and antiqui (and vetustas and antiquitas) in Roman grammarians.

${ }^{53}$ See below. In later grammarians such as Priscian, the difference between Attici and Graeci is relevant for reconstructing the sources; see E. Spangenberg Yanes, 'Le citazioni di autori greci nell'Ars di Prisciano', Athenaeum 105 (2017), 642-88, with further bibliography.

54 See K. Barwick, Remmius Palaemon und die römische Ars grammatica (Leipzig, 1922), 147-56, 188-91.

55 Cairo, Egyptian Museum inv. 4649 lines 11-12.

56 See also Quint. Inst. 1.7.18: ae syllabam, cuius secundam nunc e litteram ponimus, varie per a et $i$ efferebant, quidam semper ut Graeci, quidam singulariter tantum, cum in dativum vel genetivum casum incidissent, unde 'pictai vestis' et 'aquai' Vergilius amantissimus vetustatis carminibus inseruit, on which see A. Pennacini (ed.), Quintiliano. Institutio oratoria I (Turin, 2001), 830; as for Verrius Flaccus as possible source, see the valid arguments by Biddau (n. 46), 130. A bit later, usus litterarum is defined: hic enim est usus litterarum, ut custodiant voces et velut depositum reddant legentibus; itaque id exprimere debent quod dicturi sumus (Quint. Inst. 1.7.31).

${ }_{57}$ De Paolis (n. 30), 38.

${ }^{58}$ Virgil is also said to have employed such a form as amantissimus antiquitatis (Quint. Inst. 1.7.18). As for the recourse to the concept of metaplasmus to explain the equivalence of $e$ and $i$ and for the parallelism which the text of the anonymous grammar shows with the text of other grammatical (and especially orthographical) treatises, such as the treatise of Terentius Scaurus, see Scappaticcio (n. 1), 139-41.

59 Detailed references in Scappaticcio (n. 1), 136-9. 
presenting orthographic arguments and in passages where Verrius Flaccus is a likely source. ${ }^{60}$

Verrius is otherwise known to have analysed the matter of ai and ae. The fifth-century grammarian Pompeius refers to Verrius Flaccus and (Valerius) Cato as sources in explaining the concept of diaeresis with two Virgilian examples (Aen. 9.26, 3.354) while commenting on Donatus' chapter de metaplasmo. ${ }^{61}$ Paul the Deacon's abridgement of Festus' De verborum significatione (originally based on the great lexicon of Verrius) also justifies such a reference. ${ }^{62}$ Comparing the data is instructive, since a) a discussion of metaplasmus seems to have come from an orthographical or, less plausibly, a lexicographical work (in any case, partly linked to the name of an orthographer, Verrius), and b) from the De verborum significatione only Aen. 3.354 was an example for PaulusFestus-Verrius. The parallelism with the discussion of $-a e-/-a i$ in relation to metaplas$m u s$ by Terentius Scaurus supports the first statement. ${ }^{63}$ Instead, the latter statement raises the question of the source of Pompeius' reference to Aen. 9.26: whether from his own repertory, from Servius' commentary on Donatus, or less possibly from Verrius himself-who, on this basis, would be expected to have employed such a Virgilian hexameter for his discussion of diaeresis as an example of metaplasmus.

In any case, metaplasm must be considered an innovation of Latin grammarians in the first century B.C., ${ }^{64}$ and the anonymous author of our treatise was aware of such a concept and made it an instrument of orthographical explanation.

\section{PARS SECVNDA - ARS GRAMMATICA OR DE ORTHOGRAPHIA?}

Velius Longus' orthographical treatise also stands as a point of reference for trying to understand how our anonymous grammar was articulated. It is hypothesized that the

${ }^{60}$ Vel. Orth. 5.4 =33.1-9 Di Napoli, on which Di Napoli (n. 30), 120-1. Mar. Victor. Gramm. 4.38=76.27-8, 77.1-13 I. Mariotti, Marii Victorini Ars Grammatica (Florence, 1967), on which see Mariotti (this note), 192-3. The fourth chapter of Victorinus' grammar concerns orthography, and it is worth noting that Marius Victorinus is one of the authors to whom the definition of vox of our anonymous grammar can be paralleled. Mackensen (n. 45), 37-8 and Mariotti (this note), 62 have reconstructed a link with Verrius Flaccus, highlighting the strong analogies the passage of Victorinus has with Fest. 24.1-2: ae syllabam antiqui Graeca consuetudine per ai scribebant, ut aulai, Musai. On the link between the chapter on orthography in the Ars of Victorinus and Verrius Flaccus, see Mackensen (n. 45), 33-40.

${ }^{61}$ Pomp. Gramm. 3.65=45.4-9 A. Zago, Pompeii Commentum in Artis Donati partem tertiam (Hildesheim, 2017): nam dihaeresis est 'Albai longai' pro eo quod est 'Albae longae', ut est illud apud Vergilium, 'dives pictai vestis et auri', 'aulai medio libabant pocula Bacchi': una syllaba in duas divisa est. Legite Verrium Flaccum et Catonem, et ibi invenietis. Ita enim scribebant maiores nostri, aulai, LA et I: Graeca enim diphthongus est AI, on which see Zago (this note), 286-7.

${ }_{62}$ Paul. ex Fest. 24.1-2: ae syllabam antiqui Graeca consuetudine per ai scribebant, ut aulai, Musai. This passage is-according to Zago (n. 61), 286-7-the passage to which Pompeius would allude to.

${ }^{63}$ Ter. Orth. 5.1-2=19.13-21.5 Biddau: sequitur ut demonstremus quae littera aut praeponi possit aut subiici. 'A' igitur littera praepositiva est ' $u$ ' et ' $e$ ' litteris, 〈ut〉 'ae' et 'au'. 「Subiectiva verum enim vero ' $u$ ' sequitur ut uau; 1 et apud antiquos ' $i$ ' 'quoque litterae praeponebatur, apud quos ' $i$ ') littera pro ' $e$ ' scribebatur, ut testantur $\mu \varepsilon \tau \alpha \pi \lambda \alpha \sigma \mu o \dot{1}$, in quibus est eiusmodi syllabarum diductio, ut 'pictai vestis' et 'aulai in medio' pro 'pictae' et 'aulae'; sed magis in illis 'e' novissima sonat, et praeterea antiqui quoque Graecorum hanc syllabam per | ' $\alpha \varepsilon$ ' scripsisse traduntur, on which see Biddau (n. 46), 128-33. This passage is also analysed in parallel with the anonymous grammar from Karanis in Scappaticcio (n. 1), 135-6.

${ }^{64}$ Gutiérrez González (n. 25), 307, with further bibliography. 
treatise first discussed introductory grammatical matters-shown by the definition of dictio and the parts of speech, which must have been briefly summarized in a few lines and not explored in individual chapters as in canonical grammatical treatisesand then developed an in-depth analysis of peculiar (orthographical?) issues, such as the nature and combination of semivowels and semiconsonants. ${ }^{65}$

Did the grammatical treatise from Karanis address orthography? As may now seem obvious, there are good reasons to believe that this is a treatise de orthographia. Orthographical treatises began to be written during the Early Empire, and orthographical sections were progressively removed from the Artes grammaticae (with some later exceptions). ${ }^{66}$ Verrius Flaccus' De orthographia seems to have been the first example of such a genre, but Verrius himself must have worked with a model under his eyes; whether Verrius' model was an Ars grammatica or an orthographic treatise is impossible to determine. Nothing also stands in the way of reconstructing a grammar where orthographic matters received extensive discussion.

Alexandrian scholars never shaped their orthographical investigations into the form of a monograph. The first known monograph on orthography seems to have been the

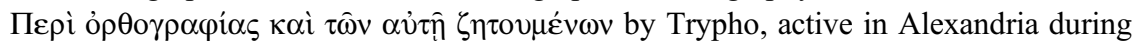
the Principate of Augustus. Trypho's work is not extant, and some subjects with which he was concerned went beyond what was traditional in Alexandria; whether the grammarian Trypho ever moved to Rome is unknown, but he must also have been active abroad. ${ }^{67}$ It has been observed that traces of Trypho's orthographical work might survive in Terentius Scaurus' de orthographia because of some evident overlapping grammatical criteria, such as the order of the orthographical canons, that is, history, etymology and analogy. ${ }^{68}$ Nothing can be observed about history, but etymology and analogy represent relevant criteria which our anonymous grammarian obeys in his argumentation, and this leads to an additional hypothesis.

Terentius Scaurus belonged to the generation before Herodian, and, as already mentioned, Verrius Flaccus' de orthographia was one of his sources; he could also have had Trypho among his models, but there is no objection to the hypothesis that Trypho was the model of a Latin source of Terentius Scaurus. Whether such a source was either Verrius Flaccus or (less possibly) Verrius' anonymous (Alexandrian) source or even a different lost grammatical treatise is impossible to say, but our anonymous grammarian could lie between Trypho and Terentius Scaurus, given the importance of the Graeci as a model for him, Terentius Scaurus and Velius Longus.

65 See Scappaticcio (n. 1), 109-11, with further explanations and bibliographical references.

66 See De Paolis (n. 30), 37, with further bibliography and an exhaustive synthesis on Latin orthography during the Roman empire.

${ }^{67}$ F. Montanari, 'Hellenistic scholarship', in F. Montanari, S. Matthaios and A. Rengakos (edd.), Brill's Companion to Ancient Greek Scholarship (Leiden and Boston, 2015), 60-183, at 180; on Trypho the grammarian, see 180-3.

${ }^{68}$ S. Valente, 'Orthography', in F. Montanari, S. Matthaios and A. Rengakos (edd.), Brill's Companion to Ancient Greek Scholarship (Leiden and Boston, 2015), 949-77, at 958-60. On the Greek treatises on orthography, see also the comprehensive account in S. Valente, 'Typology of grammatical treatises', in F. Montanari, S. Matthaios and A. Rengakos (edd.), Brill's Companion to Ancient Greek Scholarship (Leiden and Boston, 2015), 600-21, at 620 and, above all, J. Schneider, Les traités orthographiques grecs antiques et byzantins (Turnhout, 1999). On Greek scholarship from the Roman empire to Late Antiquity, see S. Matthaios, 'Greek scholarship in the Imperial Era and Late Antiquity', in F. Montanari, S. Matthaios and A. Rengakos (edd.), Brill's Companion to Ancient Greek Scholarship (Leiden and Boston, 2015), 184-296. 


\section{Readerships: second-century Egypt}

A chronological detail deserves to be emphasized. As already said, the roll bearing the fragmentary anonymous grammar from Karanis dates between the second and the third centuries A.D. The context within which this treatise was circulating undoubtedly plays a key role in understanding how a certain work found an audience even in the most peripheral areas of the Empire; in other words, how such a work would have been considered relevant enough to be copied and to circulate in a certain place and in a certain time. If this work can be attributed to Verrius Flaccus, such a statement would simply offer further proof of the good fortune this grammarian enjoyed in the second century. In fact, Suetonius, Aulus Gellius and Festus, on one side, and Velius Longus and Terentius Scaurus, on the other, all date to the second century, and all mention or count Verrius Flaccus among their sources. In the words of Lhommé, 'Verrius Flaccus, au 2éme s. apr. J.-C., est loin d'être un inconnu', ${ }^{69}$ and the roll from Karanis might be a direct witness to this fame. ${ }^{70}$

The presence of a military register involving Roman troops based in Egypt on the recto suggests that the text on the verso was also copied in Egypt, perhaps by a scribe experienced in Latin writing and based in an army office, possibly having 'access to old files from which useless documents could be extracted'. ${ }^{71}$ The aim of such a copy has long been obscure. In fact, the precious grammatical treatise was copied on 'recycled paper'. It has been imagined that there was a school where Latin was taught 'in the shadow of the barracks at Karanis', ${ }^{72}$ and a specific interest in Latin in the military bureaus in Karanis has been seen behind the circulation of such a roll. It has also been considered a personal copy of a high functionary coming from Rome, having an interest in grammar, and copying his text on 'discarded archives he had got hold of in a legal or illegal way'. ${ }^{73}$

There is no obstacle to imagining a reader interested in grammar among the army based in Karanis. The well-known correspondence between Tiberianus and Terentianus in both Latin and Greek supports such a hypothesis. ${ }^{74}$ In fact, a soldier such as Terentianus may have been interested in familiarizing himself with Latin orthographical matters, especially as an author of letters. Even non-specialists had to be sensible to the relationship between pronunciation and orthography. Suetonius describes the importance of orthography in such a way that makes clear its relevance even for a soldier. ${ }^{75}$ Furthermore, the position of orthographus legionis is attested thanks to a recommendation letter (possibly) dating to A.D. 157 from the Herakleopolites; none of his

${ }^{69}$ Lhommé (n. 43 [2007]), 40; this contribution is focussed on the popularity of Varro and Verrius in the second century A.D. and on the relationship between them, with Varro being one of the sources of Verrius.

${ }^{70}$ On the cultural vitality of Karanis, see P. van Minnen, 'House-to-house enquiries: an interdisciplinary approach to Roman Karanis', ZPE 100 (1994), 227-51; see also Calboli (n. 22), 44.

${ }^{71}$ Dunlap (n. 8), 343.

72 Dunlap (n. 8), 343.

${ }^{73}$ Wouters (n. 1), 108.

74 Scappaticcio (n. 1), 111-12.

75 Suet. Aug. 88: orthographiam, id est formulam rationemque scribendi a grammaticis institutam, non adeo custodit ac videtur eorum potius sequi opinionem, qui perinde scribendum ac loquamur existiment (...) Nec ego id notarem, nisi mihi mirum videretur tradidisse aliquos, legato eum consulari successorem dedisse ut rudi et indocto, cuius manu 'ixi' pro 'ipsi' scriptum animadverterit, on which see, for instance, G. Polara, 'Problemi di grafia del latino fra Tardo Antico e Alto Medioevo', in M. Simonetti (ed.), La cultura in Italia fra Tardo Antico e Alto Medioevo. Atti del Convegno tenuto a Roma, Consiglio Nazionale delle Ricerche, dal 12 al 16 Novembre 1979 I (Rome, 1981), 475-89, at 
tasks is known, but it is possible that they were similar to those of a librarius (responsible for accounting and correspondence) or that he was a 'grammarien et professeur d'orthographie'. ${ }^{76}$ In any case, an orthographus legionis certainly had to deal with orthography. Hence the presence of a de orthographia in a military 'library' is plausible, and such a figure could be added to the list of possible readers of the grammatical treatise from Karanis.

Whether or not it was addressed to an orthographus (or to a librarius) legionis, and whatever its readership in Karanis was supposed to be, this grammar sheds light on another matter. The systematization of Greek orthography occurred against the backdrop of second- and third-century Alexandria, evidenced by Herodianus' lost Orthography. ${ }^{77}$ Similarly the presence in Egypt of a Latin ars surely dealing with orthographical matters suggests an osmotic relationship between Latin and Greek artes, in this case with an Ars mentioning the Graeci as a model and circulating among Egyptian speakers of Greek.

\section{Before Remmius Palaemon}

The faint profile of the famous Verrius Flaccus seems to lie behind several details of the meagre grammatical Latin roll from Karanis. Verrius Flaccus is a common denominator when the contents of our fragmentary grammar are compared to attested grammatical and especially orthographical works. He seems to stand behind the adoption of analogy and etymology as defining criteria for grammatical concepts, behind the strict similarities with the orthographical works of Velius Longus and Terentius Scaurus, and behind the adoption of a Greek Alexandrian-oriented grammatical model.

At the same time, substituting Verrius as the name of the supposed Anonymus is hazardous, and the possibility that a new fragment belonging to the same roll could be found makes it impossible to declare him without hesitation the author of the text. Moreover, some features of the Ars anonyma that Verrius Flaccus was adapting have been recently identified; in fact, this anonymous grammar had to be influenced by Alexandrian grammar, dealt with parts of speech and tropes, and mentioned the doctrine of metaplasm. ${ }^{78}$ These three distinctive features align the Anonymus excerpted by Verrius Flaccus with the Anonymus whose work reached the cultural (perhaps military) environment of Karanis in the second century.

Whether the author of our treatise was the source excerpted by Verrius Flaccus or Verrius Flaccus himself-or even a grammarian sharing the same characteristics of both of them-cannot be said with certainty. What could be called 'identities' must be cautiously labelled 'analogies'. Nevertheless, not only is this fragmentary roll simply the most ancient manuscript, and so a direct witness, of a Latin grammar, but

475; De Paolis (n. 30), 42-3 (at 42); R.A. Kaster, Studies on the Text of Suetonius' De uita Caesarum (Oxford, 2016), 122-3.

${ }^{76}$ P.Hib. II 276: Iulius Repositus 'Cl(audio)' Germano suo | salutem | et praese(n)s te domine frater rogave-|-ram coram Ammonium orthogra- $\left.\right|^{5}$-phum leg(ionis) n(ostrae) amicum n(ostrum) karissi- $\left.\right|^{6}[-$ mum]. As for the possible tasks of the orthographus, see M.P. Speidel, 'Centurions and horsemen of legio II Traiana', Aegyptus 66 (1986), 163-8 and L. Robert, 'Inscriptions de l'antiquité et du bas-empire à Corinthe', REG 79 (1966), 733-70, at 754.

77 On the orthographical work by Herodian, see Valente (n. 68), 964-77, with further bibliographical references.

${ }^{78}$ An in-depth analysis is found in Gutiérrez González (n. 25), 294-6. 
also its text-whether strictly an Ars grammatica or de orthographia-is ancient enough to prove that the genre of Ars grammatica had been composed in Rome before Remmius Palaemon. ${ }^{79}$

University of Naples

'Federico II' - Project PLATINUM

MARIA CHIARA SCAPPATICCIO (ERC-StG no. 636983) mariachiara.scappaticcio@unina.it

79 The contribution of Gutiérrez González (n. 25) aims to demonstrate this and is a necessary reference point; however, our text is not mentioned at all. His persuasive arguments undermine the claims of Barwick (n. 54), which have remained popular up to M. Baratin, 'À l'origine de la tradition artigraphique latine, entre mythe et réalité', in S. Aroux, E.F.K. Koerner, H.-J. Niederehe and K. Versteegh (edd.), History of the Language Sciences I (Berlin and New York, 2000), 459-66. 